УДК 796.011 .3 “19”(477.83)

\title{
ІВАН БОБЕРСЬКИЙ ТА РОЗВИТОК СТРІЛЕЦЬКОГО РУХУ В ГАЛИЧИНІ НАПЕРЕДОДНІ ПЕРШОЇ СВІТОВОЇ ВІЙНИ
}

\author{
Андрій СОВА \\ Львівський державний університет фізичної культури \\ імені Івана Боберського, \\ вул. Тадеуша Костюшка, 11, 79000, Львів, Україна \\ e-mail: andrijsova@yahoo.com \\ DOI: $10.15330 /$ gal.32.41-47 \\ ORCID: https://orcid.org/0000-0003-0548-4975
}

\begin{abstract}
У публікації на основі періодики “Вісти з Запорожа”, “Діло”, “Ілюстрована Україна”; архівних документів, видань “Сокола-Батька”; звітів Академічної гімназї у Львові; праць Івана Боберського; фотографій та документів з приватного архіву Степана Гайдучка (м. Львів); спогадів активних учасників стрілецького руху висвітлено внесок Івана Боберського у становлення і розвиток стрілецького руху $в$ Галичині. Він, будучи головою украӥнського гімнастичного товариства “Сокіл-Батько” у 1908-1918 рр., брав активну участь у створенні стрілецьких осередків, купівлі інвентарю, підготовці відповідних фахівиів, проведенні спортивних змагань зі стрільби тощяо. Широкої популярності серед молоді набули замітки та навчально-методична праця Івана Боберського “Стрілянє до влучі” (1913). Ще одним його досягненням була розробка та уніфікація термінології зі стрільби. У словнику тодішньої молоді з'явилися терміни: “стрілянє до влучі”, “поцілка”, “влуча”, “стрілецьь”, “стрілиця”, “степінь”, “постава” тощзо. Треба віддати належне сумлінній прачі Івана Боберського, адже невдовзі чимало членів молодіжних організацій, зокрема “Сокола-Батька”, які пройшли стрілецький вишкіл, поповнили лави Легіону Українських Січових Стрільців, брали активну участь у розбудові Західно-Української Народної Республіки, воювали у лавах Галицької Армії тощо. Хронологічні межі розвідки охоплюють 1912-1914 рр.
\end{abstract}

Ключові слова: Іван Боберський, Галичина, Львів, товариство “Сокіл-Батько”, стрілецький рух.

Зважаючи на складну військово-політичну ситуацію в Європі та прогнозуючи великий військовий конфлікт, на початку XX ст. в Австро-Угорській імперії запроваджено військовоприкладну підготовку в навчальних закладах. Стрільба та загалом стрілецтво також поширилося у середовищі багатьох громадських організацій, які займалися військово-фізичною підготовкою та вишколом молоді.

Дана проблема в українській історіографії через призму діяльності Івана Боберського у становленні та розвитку стрілецького руху у Львові та Галичині не досліджувалася. Українська історіографія представлена працями узагальнюючого характеру, зокрема Осипа Думіна ${ }^{1}$, Олександра Дем'янюка ${ }^{2}$ та ін. 3 огляду на такий стан справ підготовлено цю розвідку.

Джерельною базою для статті стали: періодичні видання "Вісти з Запорожа" (друкований орган товариства “Сокіл-Батько”), “Діло”, “Ілюстрована Україна”; видання “СоколаБатька"; звіти Академічної гімназії у Львові; праці Івана Боберського; приватний архів Степана Гайдучка (м. Львів); спогади активних учасників стрілецького руху: Степана Гайдучка, Романа Дашкевича, Григорія Нички, Олени Степанів, Кирила Трильовського, Степана Шухевича.

В Академічній гімназії у Львові, де Іван Боберський викладав німецьку мову та гімнастику (фізичну культуру), “наука стріляння” інтенсивно проводилася упродовж 1912-1914 pр. Завданням цього предмету було організація військової підготовки юнаків, яка здійснювалась під наглядом військових. Упродовж навчального року, як правило, раз на тиждень, гімназисти навчалися стрільби під керівництвом професійних військових та професора гімназії. У програму навчання входило: теоретична і практична підготовка, зокрема ознайомлення зі зброєю, порохом та набоями, поводження зі зброєю тощо. Після засвоєння азів проводилися стрільби в гімназії або на малому стрільбищі полку піхоти. Зокрема, 21 березня 1914 р. в таких змаганнях

\footnotetext{
${ }^{1}$ Думін О. Історія Лєгіону Українських Січових Стрільців 1914-1918 з 99 світлинами і 23 схемами. Львів : Видавнича Кооператива “Червона Калина", 1936. 375 с.

${ }^{2}$ Дем'янюк О. Й. Український молодіжний рух Західної України : від зародження до боротьби за українську державність : монографія. Луцьк : ПВД “Твердиня”, 2007. 180 с.
} 
взяли участь 37 гімназистів Академічної гімназії. Збереглася фотографія з цих змагань, на якій як глядач та один із організаторів заходу зафіксований й Іван Боберський³

Ідея стрілецького руху дуже швидко поширилася в українських середовищах Галичини. 16 грудня 1912 р. у Львові зібрався міжпартійний комітет за участі Льонгина Цегельського, Степана Томашівського, Івана Боберського, Константини Малицької, Івана Чмоли, Миколи Балицького, Степана Гайдучка, Степана Індишевського, Романа Дашкевича та ін. На ньому було обговорено постання окремої організації під назвою "Українське стрілецьке товариство", розробку статуту, налагодження фахового військового вишколу української молоді тощо ${ }^{4}$. Однак через тактичні розбіжності, не вдалося домовитися і створити єдиний керівний орган, який би займався цими питаннями. Тому стрілецький рух розвивався паралельно в "Українському січовому союзі” (під керівництвом Кирила Трильовського), “Соколі-Батьку” (Івана Боберського) та ще в деяких самостійних осередках, які були непідконтрольні ні УСС ні “Соколу-Батьку”, .

Стрілецький рух дуже швидко поширився в українському гімнастичному товаристві “Сокіл” у Галичині. Сприяв цьому голова “Сокола-Батька” Іван Боберський. Серед активних сокільських діячів, які долучилися до розвитку в цьому напряму окрім нього були: Сень Горук, Роман та Зенон Носковські, Свген Перфецький, Олександр Довбенко, Людомир Огоновський та ін. ${ }^{6}$ І Із розвитком стрілецького руху в сокільських організаціях у 1912 р. та поширенням "вправ в стріляню" постала проблема закупівлі крісів та виготовлення "поцілок". У лютому 1913 р. 3 ініціативи Івана Боберського та за його кошти було видано “влучу для стрільців" або “поцілку” (свідоцтво результативності стрільби) для стрільби 3 крісів накладом 1 тис. примірників ${ }^{7}$. ІІї розмір становив $28,5 \times 22$ см. Кожен примірник “поцілки” був скомпонований і видрукуваний так, що після стрільби на ньому записували дату і місце проведення змагань, результати кожного стрільця та ставили підписи суддівської колегії. Таким чином кожен змагун мав доказ своєї стрілецької вправності. Іван Боберський також закупив за свої гроші два бельгійські кріси системи Комблена для соколів, щоб ті могли проводити заняття зі стрільби. Планувалося також спорудити “стрільницю” (тир) для занять. Старшина “Сокола-Батька” закликала сокільські осередки проводити польові вправи та вправи зі стрільби ${ }^{8}$. Для цього соколи закуповували “фльоберти” калібру 6 мм (карабін Флобера), кріси типу Маннліхер М95 і Верндль, облаштовували стрільниці тощо.

У 1913 р. на сторінках часопису “Вісти з Запорожа" Іван Боберський зі старшиною "Сокола-Батька” проводили роз'яснювальну роботу по стрільбі для сокільських осередків. Так, у числі 77-78 за 28 лютого 1913 р. читаємо: “Устав стрілецьких товариств відкинуло Мінїстерство для поправки деяких точок. Він буде пізнїйше затверджений. Покищо можуть філії “С[окола]-Б[атька]” вправляти ся в стріляню на підставі § 5. свого уставу. Нехай куплять собі

\footnotetext{
${ }^{3}$ [Боберський I.]. Фізичне вихованє молодежи. Звіт дирекииї и. к. академічної тімназиї у Львові за шкільний рік 1913/1914. Львів : Накладом наукового фонду, 1914. С. 46-55.

${ }_{5}^{4}$ Думін О. Історія Лєгіону Українських Січових Стрільців 1914-1918 з 99 світлинами і 23 схемами... С. 15. ${ }^{5}$ Центральний державний історичний архів України у Львові. Ф. 360. Оп. 1. Спр. 48. Арк. 1-12 ; Трильовський К. В справі Товариств “Сїчові Стрільцї”. Запорожець : Калєндар для народа на рік звичайний 1914 / уложили д-р К. Трильовський і Іван Чупрей. Коломия : Накладом д-ра К. Трильовського, 1913. C. 142-152 ; Давний Р. [Дашкевич Р.]. Початки Українських Січових Стрільців. Запорожещь. Калєндар для народа на рік звичайний 1921 / уложив д-р Кирило Трильовський. Відень : Накладом д-ра Кирила Трильовського, 1921. С. 56-66 ; Трильовський К. 3 моїх споминів. Початки стрілецької організації і “Боєва Управа”. Історичний калєндар-альманах Червоної Калини на 1927 рік. Львів : Київ, 1926. С. 1-17 ; Шухевич С. Видиш брате мій (8 місяців серед УСС-ів). Львів, 1930. С. 7-11 ; Степанів О. Напередодні великих подій: Власні переживання і думки. 1912-1914. Львів : Червона Калина, 1930. С. 31-32; Дашкевич Р., Ничка Г. Товариство “Повітова Січ” у Львові. Гей, там на горі “Січ” іде! Пропам'ятна книга "Січей". Едмонтон, 1965. С. 230-248.

${ }^{6}$ Шухевич С. Видиш брате мій (8 місяців серед УСС-ів). Львів, 1930. С. 11.

${ }^{7}$ Гайдучок С. Пів століття сокільських видань. Львів, 1937. С. 37.

${ }^{8}$ Вправи полеві. Вісти з Запорожа. Часопись руханкових, змагових, мандрівних і пожарних товариств. Львів, 1913. 28 лютого. Чис. 77-78. С. 12 ; Сокіл-Батько. Вправи в стріляню. Вісти з Запорожа. Часопись руханкових, змагових, мандрівних і пожарних товариств. Львів, 1913. 28 лютого. Чис. 77-78. С. 12.
} 
фльоберти калїбру 6 мілїметрів (15-50 К[орон]) і стріляють до влучі в комнатї. Сто патронів коштує 1 корона. Коли Т[оварист]во уладить малу стрільницю, добре обезпечену, то можна стріляти 3 такого фльоберту на свобіднім воздусї. Хто хоче на стрільницї товариства стріляти 3 більшої ручницї або карабіна, то мусить мати на стрілянє дозвіл староства і оружну карту (ваффенпас). Стрільницю треба уладити так як військову а дозвіл на ню дає староство. Військові кріси (карабіни) дістануть наші товариства “С[окола]-Б[атька]” тодї, наколи головна команда полагодить прихильно подане “С[окола]-Б[атька]”, яке відносить ся до всіх філїй. Хто хоче собі купити кріс взору Манлїхера, той дістане єго за 104 корон разом з багнетом і ременем. Коли команда полагодить подане “С[окола]-Б[атька]”, тодї дістануть товариства якесь число військових крісів і будуть могли вчити ся стріляня на військових стрільницях. Патрони платить ся".

У 1913 р. Іван Боберський написав навчально-методичний посібник "Стрілянє до влучі", ньому було подано коротку інформацію про зброю для стріляння, методику, правила змагань зі стрільби, техніку безпеки тощо. Серед іншого там було зазначено: "В уставі філїй “СоколаБатька” наведене $є$ між руханковими вправами також стрілянє. $Є$ се вправа, яка вироб- ляє бистрість ока і підготованє до оборони. [...] Кожда вправа в стріляню мусить відбувати ся під доглядом начальника чи там отамана або їх заступників. Стрілянє з 6-мілїметрового фльоберту не вимагає окремого дозволу державних властий. Наколи би товариство хотїло стріляти 3 більших ручниць, в такїм разї мусить уладити собі стрільницю після війскового взору і постарати ся о право стріляня з ручниц" ${ }^{\text {"11 }}$.

Іван Боберський розробив та уніфікував термінологію зі стрільби. У словнику соколів 3'явилися терміни: “стріляне до влучі”, “поцілка”, “влуча”, “стрілець”, “стрілиця”, “степінь”, “постава" тощо. У 1914 р. він планував видати докладнішу працю зі стрільби. Однак його ініціативам завадила Перша світова війна.

27 грудня 1913 р. відбулися загальні збори стрілецького куреня, який діяв при товаристві "Сокіл-Батько" . Сокільський часопис "Вісти з Запорожа" на початку 1914 р. змінив назву з "Вісти з Запорожа. Часопись руханкових, змагових, мандрівних і пожарних товариств" 13 на "Вісти з Запорожа. Руханка, Змаг, Пожарництво, Мандрівництво, Пласт, Стрілецтво" 14.

Важливим у популяризації стрільби серед членів “Сокола", руханкових, спортових, парамілітарних товариств та широкої громадськості було проведення спортивних змагань. Перше “стрілянє до влучі” відбулося 10 лютого 1913 р.; Друге - 19 квітня 1913 р.; Третє 8 листопада 1913 р.; Четверте - 7 березня 1914 р.; П’яте (не відбулося, планувалося на 29 червня 1914 р. $)^{15}$. Змагання проводилися в рухівні “Сокола-Батька” на вул. Руська, 20. Незмінним організатором та головою суддівської колегії на них був Іван Боберський.

На Першому “стрілянні до влучі" найкращими стрільцями “Сокола-Батька” були Володимир Неділка (перше місце), Юрій Вінцковський (друге), Семен Магаляс (трете) ${ }^{16}$.

\footnotetext{
${ }^{9}$ Сокіл-Батько. Вправи в стріляню... С. 12.

10 Бб [Боберський I.]. Стрілянє до влучі. Калєндар “Вістий з Запорожа” на 1914 рік. Львів : Наклад редакциї "Вістий з Запорожа", 1913. С. 58-63.

${ }^{11}$ Там само. С. 58, 63.

12 Загальні Збори. Вісти з Запорожа. Часопись руханкових, змагових, мандрівних і пожарних товариств. Львів, 1913. 30 грудня. Чис. 86-88. С. 12.

${ }^{13}$ Вісти з Запорожа. Часопись руханкових, змагових, мандрівних і пожарних товариств. Львів, 1913. 30 жовтня. Чис. 86 А. 8 с.

${ }^{14}$ Вісти з Запорожа. Руханка, Змаг, Пожарництво, Мандрівництво, Пласт, Стрілеитво. Львів, 1914. 28 лютого. Чис. 89-90. 12 с.

${ }^{15}$ I. стріляне до влучі. Вісти з Запорожа. Часопись руханкових, змагових, мандрівних і пожарних товариств. Львів, 1913. 28 лютого. Чис. 77-78. С. 12 ; Гайдучок С. Стрілянє. Ілюстрована Україна. Львів, 1913. 8 марта. Ч. 5. С. 14 ; Стріляне до влучі. Діло. Львів, 1913. 18 квітня. Чис. 86. С. 5 ; III. нагородне стрілянє до влучі. Діло. Львів, 1913. 8 грудня. Чис. 273. С. 6 ; Четверті нагородні змаганя в стріляню. Діло. Львів, 1914. 5 марта. Чис. 49. С. 6 ; Світлини. Приватний архів Степана Гайдучка (м. Львів).

${ }^{16}$ I. стріляне до влучі. Вісти з Запорожа. Часопись руханкових, змагових, мандрівних і пожарних товариств. Львів, 1913. 28 лютого. Чис. 77-78. С. 12.
} 


\section{4}

25 квітня 1914 р. в сокільській рухівні на вул. Руській, 20 відбулися надзвичайні загальні збори "Сокола-Батька" ". На них з подачі Івана Боберського було прийнято поправки до назви товариства, яка стала звучати так: “руханково-стрілецьке товариство “Сокіл”“. Це було зроблено з огляду на те, що в організації упродовж 1912-1914 рр. активно проводився парамілітарний вишкіл членів товариства. У травня 1914 р., після багатьох дискусій та обговорень, з'явився правильник однострою для стрілецьких куренів під керівництвом “Сокола-Батька", а також постанови для стрілецьких старшин ${ }^{18}$.

Напередодні війни парамілітарний вишкіл все більше і більше поширювався серед членів сокільських товариств у Галичині. 3 огляду на те, що виникало чимало питань 3 організацією стрілецтва, у липні 1914 р. на сторінках часопису "Вісти з Запорожа" опубліковано роз'яснення стосовно цього: "Не потрібно закладати осібні стрілецькі товариства, бо через се роздїлюєм наші сили, наші гроші і наш час. Коли маємо товариство "Сїч" або "Сокіл”, то се товариство має заняти ся руханкою, пожарництвом, пластом а також стрілецтвом. Котра "Сїч" або котрий "Сокіл" хотять поширити стрілецтво, то пригадуємо, що в уставі товариств “С[окола]-Б[атька]” стоїть від 20 лїт параграф, що товариство занимає ся вправами в стріляню до цїли. Після закону можуть війскові власти позволити до науки війскову стрільницю лише товариствам, що мають назву "Schützenverein". Для того треба на загальні збори товариства поставити “зміну уставу” і додати в назві товариства слово “стрілецький”. Тодї буде назва звучала: Стрілецьке і руханкове товариство “Сїч” (“Сокіл”) або Стрілецьке пожарне і рухаукове товариство “Сїч” (“Сокіл”). В точцї про вправи товариства треба додати “полеві вправи”, а в точцї про салю товариства додати "стрільницю". Є се зміни, потрібні лише в відносинах до війскових властий. Товариство з таким уставом носить виразно назву “Стрілецьке товариство" "Schützenverein" а війскові круги після закона можуть на відповідну письменну просьбу позичити до науки кілька крісів і позволити на стрілянє до влучі в війсковій стрільниці" 19 .

Певним підсумком діяльності стрілецьких куренів при “Соколі-Батьку” під керівництвом Івана Боберського став Шевченківський здвиг у Львові. На ньому вони були представлені: від "Сокола" - 78 осіб в одностроях, від “Січі" - 146 осіб ${ }^{20}$. УСС виконали вправи вільноруч, зі списами та крісами. Андрій Баб'юк про ці парамілітарні товариства зазначав: “І по цілій Галичині почали наші люде засновувати товариства "Січові Стрільці" - в яких учили молодих хлопців військових вправ. До товариства вписувався кождий, хто хотів. Впротягу одного року таких товариств було вже 86 по цілій Галичині і то не тільки в містах, але й по селах. Молоді хлопці радо вписувалися до “Січових Стрільців” і кождий навіть гордився тим, що належить до них",21.

У серпні 1914 р. Іван Боберський у замітці в "Вістях з Запорожа” писав: “Доперва в часї небезпеченьства видить кождий, шо роздроблені сили є слабі. Гроза війни спонукала всї три партиї політичні Українців в Галичинії, що утворили 25. липня 1914 [р.] "Головну Українську Раду" - а ся Рада зарядила, шо цїла суспільність творить одну велику громаду. Націонал-демо-

крати, соціял-демократи і радикали розуміють тепер дуже добре, що коли хотять поставити в поле добровольцїв, то мусять се зробити “Всі враз”! Коли був спокій в державі, не можна було проводирів переконати, що лише спільна робота може зорганізувати сильний союз руханкових і

\footnotetext{
${ }^{17}$. Королик Р. Надзвичайні загальні збори "Сокола-Батька". Вісти з Запорожа. Руханка, Змаг, Пожарництво, Мандрівництво, Пласт, Стрілецтво. Львів, 1914. 15 мая. Чис. 93. С. 2.

${ }^{18}$ Бабин Е. Стрілецький однострій. Вісти з Запорожа. Руханка, Змаг, Пожарниџтво, Мандрівниџтво, Пласт, Стрілецтво. Львів, 1914. 15 мая. Чис. 93. С. 6 ; Постанови що до стрілецьких старшин в організациї “С.-Б.”. Вісти з Запорожа. Руханка, Змаг, Пожарництво, Мандрівництво, Пласт, Стрілецтво. Львів, 1914. 15 мая. Чис. 93. С. 7-8 ; Краска вилогів стрільцїв організациї “С.-Б.”. Вісти з Запорожа. Руханка, Змаг, Пожарниитво, Мандрівництво, Пласт, Стрілеитвво. Львів, 1914. 15 мая. Чис. 93. С. 8.

${ }^{19}$ Бабин Е. Стрілецтво. Вісти з Запорожа. Руханка, Змаг, Пожарництво, Мандрівниитво, Пласт, Стрілецтво. Львів, 1914. 30 липня. Чис. 95-96. Подвійне число. С. 10.

${ }^{20}$ Шевченковий ювилейний здвиг у Львові 27. 28. 29. VI. 1914. (Жерельний звіт з роботи для науки на будучність). Вісти з Запорожа. Руханка, Змаг, Пожарниџтво, Мандрівниџтво, Пласт, Стрілецтво. Львів, 1914. 30 липня. Чис. 95-96. Подвійне число. С. 4-7.

${ }^{21}$ Ірчан М. [Баб'юк А.]. Хто такі У.С.С.? Полевий поштовий пост. Ч. 9 / Накладом редакції часопису "УCC". 1919. С. 2-3.
} 
стрілецьких товариств. Тепер є війна і кождий се розуміє, що в злуцї сила. Ся наука приходить для неодного пізно, але нехай она лишить ся і на час, коли небезпека мине. 3 органїзацій руканкових, руханково-стрілецьких і стрілецьких товариств належить безусловно усунути особисті амбіциї і забаганки, та всї тоті товариства злучити в один сильний союз, який буде міг зібрати значнійші гроші на свою ціль і без сварки виконати основну роботу. Небезпека показала тепер, що се можна зробити, длятого треба се зробити. Всі “Соколи”, всї “Сїчи”, всї “Стрільці” повинні утворити один Союз так як тепер творять они спільно гурт добровольцїв під назвою "Українських Січових Стрільців". В тій органїзациї працюють всї спільно розуміють щораз лїпше, що не слова, але дїла творять сильну роботу"22.

Отже, Іван Боберський, будучи головою українського товариства “Сокіл-Батько” у 1908-1918 рр., відіграв важливу роль у становленні та розвитку стрілецького руху в Галичині. Зокрема, він брав активну участь у створенні стрілецьких осередків, купівлі інвентарю, підготовці відповідних фахівців, організації та проведенні спортивних змагань зі стрільби тощо. Широкої популярності серед молоді набули його замітки та навчально-методична праця "Стрілянє до влучі" (1913). Значним досягненням стала розробка та уніфікація термінології зі стрільби (у словнику того часу з'явилися терміни: “стріляне до влучі”, “поцілка", “влуча", “стрілець”, “стрілиця”, “степінь”, “постава” тощо. Завдяки сумлінній праці Івана Боберського, члени молодіжних організацій, зокрема "Сокола-Батька”, які пройшли стрілецький вишкіл, а також січовики, пластуни, січові стрільці, члени спортивних товариств поповнили лави Легіону Українських січових стрільців, брали активну участь у розбудові Західно-Української Народної Республіки, воювали у лавах Галицької Армії тощо. На фронтах Першої світової війни соколи зі зброєю в руках самовіддано боролися за майбутню долю України, а їхній голова Іван Боберський упродовж 1914-1918 pp. - член та скарбник Бойової управи Українських січових стрільців (з 1917 р. - Центральної управи УСС), 1914-1915 pр. - член Головної української ради, 1915-1916 рр. - член Загальної української ради, 1918-1919 рр. - референт "Письменничого відділу" в Державному секретаріаті військових справ Західно-Української Народної Республіки.

\title{
IVAN BOBERSKY AND THE DEVELOPMENT OF THE RIFLE MOVEMENT IN HALYCHYNA A DAY BEFORE THE FIRST WORLD WAR
}

\author{
Andrii SOVA \\ Lviv state university of physical culture \\ the name of Ivan Boberskyi, \\ Kostiushka St., 11, 79000, Lviv, Ukraine \\ e-mail:andrijsova@yahoo.com
}

\begin{abstract}
Summary
In the publication Ivan Bobersky's contribution to the formation and development of the rifle movement in Galicia was illuminated on the basis of the periodicals "Visty z Zaporozha" (News from Zaporozha), "Dilo" (Action), "Iliusrtrovana Ukraina" (Illustrated Ukraine); archival documents, editions of "Sokil-Batko" (FalconFather); reports of the Academic High School in Lviv; works of Ivan Beaverski y; photos and documents from the private archive of Stepan Gaiduchko (Lviv); memoirs of active participants of the rifle movement. He as a chairman of the Ukrainian Gymnastic Society "Sokil-Batko" in 1908-1918 actively participated in the creation of small rifle centers, the purchase of inventory, training of specialists, conducting sports rifle competitions and more. Remarks and educational and methodological work of Ivan Boberskyi "Strilianie do vlychi" (Shoot to hit) (1913) became very popular among young people. Another achievement was the development and unification of rifle terminology. In the vocabulary of the youth of that time, the terms as "striljanje do vlychi" (target shooting), "potiilka" (target), "vlycha" (target), "striletc" (rifleman), "strilytcja" (riflewoman), "degree", "posture" and more appeared. It is necessary to pay tribute to the conscientious work of Ivan Boberskiy, as soon enough many members of youth organizations, in particular, "Sokil-Batko", who passed rifle training,
\end{abstract}

\footnotetext{
${ }^{22}$ Бб [Боберський I.]. Доперва в часї небезпеченьства. Вісти з Запорожа. Руханка, Змаг, Пожарництво, Мандрівництво, Пласт, Стрілецтвво. Львів, 1914. 8 серпня. Чис. 97. Число добровольцїв. С. 8.
} 
replenished the ranks of the Legion of Ukrainian Sich Riflemen, actively participated in the development of the Western Ukrainian People's Republic, fought in the ranks of the Galician army, etc. The chronological limits of exploration cover 1912-1914.

Keywords: Ivan Boberskyi, Halychyna, Lviv, "Sokil-Batko” society, small rifle movement.

\section{REFERENCES}

Babyn E. Striletstvo. Visty z Zaporozha. Rukhanka, Zmah, Pozharnytstvo, Mandrivnytstvo, Plast, Striletstvo. Lviv, 1914. 30 lypnia. Chys. 95-96. Podviine chyslo. S. 10. [in Ukrainian].

Babyn E. Striletskyi odnostrii. Visty z Zaporozha. Rukhanka, Zmah, Pozharnytstvo, Mandrivnytstvo, Plast, Striletstvo. Lviv, 1914. 15 maia. Chys. 93. S. 6. [in Ukrainian].

Bb [Boberskyi I.]. Doperva v chasi nebezpechenstva. Visty z Zaporozha. Rukhanka, Zmah, Pozharnytstvo, Mandrivnytstvo, Plast, Striletstvo. Lviv, 1914. 8 serpnia. Chys. 97. Chyslo dobrovoltsiv. S. 8. [in Ukrainian]. Bb [Boberskyi I.]. Strilianie do vluchi. Kaliendar "Visty z Zaporozha” na 1914 rik. Lviv : Naklad redaktsii "Visty z Zaporozha", 1913. S. 58-63. [in Ukrainian].

[Boberskyi I.]. Fizychne vykhovanie molodezhy. Zvit dyrektsyi ts. k. akademichnoi gimnazii u Lvovi za shkilnyi rik 1913/1914. Lviv : Nakladom naukovoho fondu, 1914. S. 46-55. [in Ukrainian].

Visty z Zaporozha. Rukhanka, Zmah, Pozharnytstvo, Mandrivnytstvo, Plast, Striletstvo. Lviv, 1914. 28 liutoho. Chys. 89-90. 12 s. [in Ukrainian].

Visty z Zaporozha. Chasopys rukhankovykh, zmahovykh, mandrivnykh i pozharnykh tovarystv. Lviv, 1913. 30 zhovtnia. Chys. 86 A. 8 s. [in Ukrainian].

Vpravy polevi. Visty z Zaporozha. Chasopys rukhankovykh, zmahovykh, mandrivnykh i pozharnykh tovarystv. Lviv, 1913. 28 liutoho. Chys. 77-78. S. 1. [in Ukrainian].

Haiduchok S. Piv stolittia sokilskykh vydan. Lviv, 1937. 53 s. [in Ukrainian].

Haiduchok S. Strilianie. Iliustrovana Ukraina. Lviv, 1913. 8 marta. Ch. 5. S. 14. [in Ukrainian].

Davnyi R. [Dashkevych R.]. Pochatky Ukrainskykh Sichovykh Striltsiv. Zaporozhets. Kaliendar dlia naroda na rik zvychainyi 1921 / Ulozhyv Doktor Kyrylo Trylovskyi. Viden : Nakladom Dra Kyryla Trylovskoho, 1921. S. 56-66. [in Ukrainian].

Dashkevych R., Nychka H. Tovarystvo "Povitova Sich" u Lvovi. Hei, tam na hori "Sich” ide! Propamiatna knyha "Sichei". Edmonton, 1965. S. 230-248. [in Ukrainian].

Dumin O. Istoriia Liegionu Ukrainskykh Sichovykh Striltsiv 1914-1918 z 99 svitlynamy i 23 skhemamy. Lviv : Vydavnycha Kooperatyva "Chervona Kalyna”, 1936. 375 s. [in Ukrainian].

Zahalni Zbory. Visty z Zaporozha. Chasopys rukhankovykh, zmahovykh, mandrivnykh i pozharnykh tovarystv. Lviv, 1913. 30 hrudnia. Chys. 86-88. S. 12. [in Ukrainian].

I. strilianie do vluchi. Visty z Zaporozha. Chasopys rukhankovykh, zmahovykh, mandrivnykh i pozharnykh tovarystv. Lviv, 1913. 28 liutoho. Chys. 77-78. S. 12. [in Ukrainian].

III. nahorodne strilianie do vluchi. Dilo. Lviv, 1913. 8 hrudnia. Chys. 273. S. 6. [in Ukrainian].

Irchan M. [Babiuk A.]. Khto taki U.S.S.? Polevyi poshtovyi post. Ch. 9 / Nakladom redaktsii chasopysu "USS". 1919. 16 s. [in Ukrainian].

Korolyk R. Nadzvychaini zahalni zbory "Sokola-Batka”. Visty z Zaporozha. Rukhanka, Zmah, Pozharnytstvo, Mandrivnytstvo, Plast, Striletstvo. Lviv, 1914. 15 maia. Chys. 93. S. 2. [in Ukrainian].

Kraska vylohiv striltsiv organizatsyi "S.-B.". Visty z Zaporozha. Rukhanka, Zmah, Pozharnytstvo,

Mandrivnytstvo, Plast, Striletstvo. Lviv, 1914. 15 maia. Chys. 93. S. 8. [in Ukrainian].

Postanovy shcho do striletskykh starshyn v organizatsyi "S.-B.”. Visty z Zaporozha. Rukhanka, Zmah,

Pozharnytstvo, Mandrivnytstvo, Plast, Striletstvo. Lviv, 1914. 15 maia. Chys. 93. S. 7-8. [in Ukrainian].

Svitlyny. Pryvatnyi arkhiv Stepana Haiduchka (m. Lviv). [in Ukrainian].

Sokil-Batko. Vpravy v strilianiu. Visty z Zaporozha. Chasopys rukhankovykh, zmahovykh, mandrivnykh i pozharnykh tovarystv. Lviv, 1913. 28 liutoho. Chys. 77-78. S. 12. [in Ukrainian].

Stepaniv O. Naperedodni velykykh podii: Vlasni perezhyvannia i dumky. 1912-1914. Lviv : Chervona Kalyna, 1930. 45 s. + 12 s. il. [in Ukrainian].

Strilianie do vluchi. Dilo. Lviv, 1913. 18 kvitnia. Chys. 86. S. 5. [in Ukrainian].

Trylovskyi K. V spravi Tovarystv "Sichovi Striltsi". Zaporozhets. Kaliendar dlia naroda na rik zvychainyi 1914 / Ulozhyly Dr K. Trylovskyi i Ivan Chuprei. Kolomyi a: Nakladom D-ra K. Trylovskoho, 1913. S. 142-152. [in Ukrainian].

Trylovskyi K. Z moikh spomyniv. Pochatky striletskoi orhanizatsii i "Boieva Uprava". Istorychnyi kaliendar-almanakh Chervonoi Kalyny na 1927 rik. Lviv ; Kyiv, 1926. S. 1-17 [in Ukrainian].

Tsentralnyi derzhavnyi istorychnyi arkhiv Ukrainy u Lvovi. F. 360. Op. 1. Spr. 48. 12 ark. (Statut tovarystva "Sichovykh striltsiv" u Lvovi i proekt yoho dopovnen i zmin, skladenykh Starosolskym Volodymyrom, a takozh pershi nakazy obranoi heneralnoi starshyny). [in Ukrainian]. 
Chetverti nahorodni zmahania v strilianiu. Dilo. Lviv, 1914. 5 marta. Chys. 49. S. 6. [in Ukrainian].

Shevchenkovyi yuvyleinyi zdvyh u Lvovi 27. 28. 29. VI. 1914. (Zherelnyi zvit z roboty dlia nauky na buduchnist). Visty z Zaporozha. Rukhanka, Zmah, Pozharnytstvo, Mandrivnytstvo, Plast, Striletstvo. Lviv, 1914. 30 lypnia. Chys. 95-96. Podviine chyslo. S. 4-7. [in Ukrainian].

Shukhevych S. Vydysh brate mii (8 misiatsiv sered USS-iv). Lviv, 1930. 232 s. [in Ukrainian]. 